UDC 631.41

\title{
DYNAMICS OF PLANT-AVAILABLE PHOSPHORUS IN THE LONG-TERM FIELD EXPERIMENT WITH FERTILIZERS ON CALCAREOUS CHERNOZEM OF MOLDOVA
}

\author{
D. M. Indoitu, dr. agr. \\ ORCID ID: 0000-0001-7475-0689, \\ D. D. Indoitu \\ ORCID ID: 0000-0003-4190-7816, \\ State Agrarian University of Moldova
}

https://doi.org/10.31734/agronomy2019.01.222

Індоіту Д. М., Індоіту Д. Д. Динаміка рухомих форм фосфору в довгостроковому польовому експерименті з добривами на карбонатному чорноземі Молдови

Фосфор - це один із необхідних для росту й розвитку рослин макроелементів. Джерелом фосфору для рослин є грунт і добрива. Родючість грунту залежить від вмісту фосфору. Вирощування сільськогосподарських культур без і з різними системами удобрення по-різному впливає на вміст доступного фосфору в грунті. У сучасних методах ведення сільського господарства, оскільки грунт часто експлуатується, спостереження за вмістом рухомого фосфору та напрямом його зміни $є$ актуальним. Це можливо тільки в тривалих експериментах. Наші дослідження були проведені в довгостроковому стаціонарному польовому експерименті з різними системами удобрення на дослідній станції «Кетроси» Державного аграрного університету Молдови. Дослідження проводили на карбонатних чорноземах у 1953-2018 роках. Доступний фосфор визначали за методом Мачигіна. Зразки грунту взяті навесні під пшеницею озимою з глибини від 0 до 60 см. Динаміку доступного фосфору вивчали на трьох дослідних ділянках: без внесення добрив 31950 року; 3 впливом малих доз мінеральних добрив (в середньому $\mathrm{N}_{47} \mathrm{P}_{46}$ на рік); 3 попереднім довгостроковим застосуванням мінеральних і органічних добрив. На ділянках з природною родючістю карбонатних чорноземів (без внесення добрив з 1950 року) вміст доступного фосфору знизився у верхньому шарі грунту (у шарі 0-20 см) з 1,65 мг/100 г (у період 1953-1962 років) до 0,91 мг/100 г грунту (у період 2006-2013 років), у шарі 20-40 см - від 1,55 мг/100 г до 0,75 мг/100 г грунту, в шарі 40-60 см - від 1,0 мг/100 г до 0,5 мг/100 г грунту. Після внесення пожнивних решток і всіх побічних продуктів цей вміст становив 1,6 мг/100 г, 1,1 мг/100 г i 0,7 мг/100 г грунту відповідно. На систематично удобрених ділянках він збільшився у 2,7-2,9 раза. Оптимальний вміст доступного фосфору в грунті для озимої пшениці становить 3,0-4,0 мг/100 г грунту. Використання низьких доз мінеральних добрив у період 2006-2018 років разом із рослинними рештками і всіма побічними продуктами дещо зменшило цей вміст, але з часом дало змогу зберегти його рівень.

Ключові слова: рухомі форми фосфатів, карбонатний чорнозем, системи удобрення, динаміка.

Indoitu D. M., Indoitu D. D. Dynanics of plant-available phosphorus in the long-term field experiment with fertilizers on calcareous chernozem of Moldova

Phosphorus is an essential macronutrient for plant growth and development. The sources of phosphorus for plants are soil and fertilizers. Soil fertility depends on the phosphorus content. Crop cultivation without and with different fertilizing systems influences the content of available phosphorus in the soil in different ways. In modern agricultural practices, as the soil has been frequently over exploited, the tracking of the available phosphorus content and the direction of its change has a topical interest. This is possible only in long-term experiments. Our studies were conducted in the long-term field experiment with different fertilizing systems at the experimental Station «Ketrosy» of the State Agrarian University of Moldova. The research was carried out on Calcareous chernozem in the 1953-2018 period. Available phosphorus was determined according to the Machigin method. Soil samples were taken under winter wheat from the 0- to 60-cm depth in the spring. The dynamics of available phosphorus was studied on three experimental plots: without fertilization from 1950, with influence of small doses of mineral fertilizers (on average $\mathrm{N}_{47} \mathrm{P}_{46}$ per year) on variants with previous long-term application of mineral and organic fertilizers. On plots with natural fertility of Calcareous chernozem (without fertilizers), the content of available phosphorus decreased in the topsoil (in the 0-20 cm layer) from 1,65 (in the 1953-1962 period) to $0,91 \mathrm{mg} .100 \mathrm{~g}^{-1}$ soil (in the $2006-2013$ period), in the $20-40 \mathrm{~cm}$ layer - from 1,55 to $0,75 \mathrm{mg} .100 \mathrm{~g}^{-1}$ soil, in the $40-60 \mathrm{~cm}$ layer - from 1,0 to $0,5 \mathrm{mg} .100 \mathrm{~g}^{-1}$ soil. After introducing of crop residues and all by-products this content was $1,6,1,1$ and $0,7 \mathrm{mg} .100 \mathrm{~g}^{-1}$ soil, respectively. On systematically fertilized plots it increased by 2,7-2,9 times. The optimal content of available phosphorus in the soil for winter wheat is $3,0-4,0 \mathrm{mg} .100 \mathrm{~g}^{-1}$ soil. The use of low doses of mineral fertilizers in the period 2006-2018, together with plant residues and by-products, slightly reduced this content, but with time it allowed to maintain its level.

Key words: mobile forms of phosphorus, calcareous chernozem, fertilizing systems, dynamics. 
Problem setting. Phosphorus is one of the essential nutrients for plants and contributes to the formation of a quality and high-level crop yield [4]. The phosphorus content determines soil fertility. The provision of soil with available phosphorus is considered to be one of the main signs of good soil cultivation.

Long-term crop cultivation with and without fertilizers affects the phosphorus content in the soil and, accordingly, its fertility. Therefore, it is very important to track the dynamics of its mobile compounds in order to make recommendations for replenishing the needs of plants in phosphorus.

Analysis of the recent researches and publications. The source of phosphorus for plants are soil and fertilizers. The total phosphorus content depends on soil humification, the amount of this element in the soil-forming rock and the amount of fertilizers applied. In Moldova's chernozems this content is $140-180 \mathrm{mg} .100 \mathrm{~g}^{-1}$ soil $[1 ; 6]$. The ability of soils to provide plants with phosphorus is closely related to the interaction of various forms of phosphates, which differ in their mobility and availability to plants. Phosphorus is found in mineral and organic forms of compounds. The available phosphorus reserves for plants are organic compounds - in chernozem 30-70\% of the total content. Mineral forms of phosphorus: compounds of orthophosphoric acid with $\mathrm{Ca}, \mathrm{Mg}, \mathrm{Fe}, \mathrm{Al}, \mathrm{Mn}$ and $\mathrm{Ti}$ ions [5]. Calcareous chernozem in Moldova is characterized by a significantly higher content of mineral phosphorus than other chernozems [4]. The splitting of sparingly soluble mineral phosphates and the decomposition of organic forms generates soluble phosphorus compounds.

Task setting. The goal of our research was to study the dynamics of mobile forms of phosphorus in Calcareous chernozem of Moldova in a long-term experience with using various fertilizer systems in the field crop rotation.

Main results. The studies were conducted at the Experimental Station "Ketrosy" of the State Agrarian University of Moldova in the long-term field experience with fertilizers.

The eight-field crop rotation: maize for grain peas for grain - winter wheat - winter wheat - maize for grain - peas for grain - winter wheat - sunflower. The soil is Calcareous chernozem (Calcic chernozem): light loam with 2,5-3,0 \% humus (Tyurin), 0,8-1,5 mg.100 $\mathrm{g}^{-1}$ soil mobile phosphate (Machigin), 18-22 mg.100 $\mathrm{g}^{-1}$ soil exchangeable potassium and $1,8-2,2 \%$ carbonates in the $0-20 \mathrm{~cm}$ layer. This rotation was put in place after two complete cycles of ten-field crop rotation with low doses of fertilizer (1950-1970). Since 1971, a system of fertilization for the planned yield was used in the eight-field crop rotation: annual applications of 300 $\mathrm{kg}$ NPK.ha ${ }^{-1}$ of mineral fertilizers $-\mathrm{N}_{120} \mathrm{P}_{90} \mathrm{~K}_{90}$ $\left(\mathrm{N}_{90} \mathrm{P}_{60} \mathrm{~K}_{60}\right.$ from 1999); an equivalent annual application of farmyard manure at 24 t.ha ${ }^{-1}\left(18\right.$ t.ha ${ }^{-1}$ from 1999); combined manure at 12 t.ha $^{-1}+$ mineral $\mathrm{N}_{60} \mathrm{P}_{60} \mathrm{~K}_{45}\left(9\right.$ t.ha ${ }^{-1}$ manure + mineral $\mathrm{N}_{45} \mathrm{P}_{45} \mathrm{~K}_{30}$ from 1999). Since 2005, the aftereffect of fertilizers has been studied. Since 2008, the minimum doses required of $\mathrm{N}_{47} \mathrm{P}_{46}$ mineral fertilizers have been introduced with the application of all plant residues (stalks, stubble, roots). Three experimental plots: without fertilization from 1950, with influence of small doses of mineral fertilizers (on average $\mathrm{N}_{47} \mathrm{P}_{46}$ per year) on variants with previous long-term application of mineral $\left(\mathrm{N}_{90} \mathrm{P}_{60} \mathrm{~K}_{60}\right)$ and organic (18 t.ha ${ }^{-1}$ manure) fertilizers.

The following mineral fertilizers were used: ammophos during sowing, ammonium nitrate during top dressings, manure (until 2005) for maize for grain. The plant residues, including by-products of cultivated crops, were crushed during harvesting by the combine harvester and embedded in the soil: for winter wheat, during surface primary processing with disk implements, for corn, sunflower by plowing to a depth of $25-27 \mathrm{~cm}$. The crop rotation is set up in three 2 ha fields, the area of each experimental plot is $200 \mathrm{~m}^{2}(20 \times 10 \mathrm{~m}), 3$ replicates. Available phosphorus was determined according to the Machigin method $[2 ; 3]$ during spring at the beginning of the growing of winter wheat.

During the 1953-1972 period (which means two rotations of the 10-field crop rotation) fertilizers were used in small doses - on average 2 t.ha $^{-1}$ of manure $+\mathrm{N}_{5} \mathrm{P}_{12} \mathrm{~K}_{11}$. The content of available phosphorus in the soil was $1,55-2,60 \mathrm{mg} .100 \mathrm{~g}^{-1}$ soil, compared with the available phosphorus of the control without fertilizers $1,40-1,65 \mathrm{mg} .100 \mathrm{~g}^{-1}$ (figure).

In 1973 the eight-field crop rotation was introduced. The doses of fertilizers were for the planned crop yield: for winter wheat $-\mathrm{N}_{90-150} \mathrm{P}_{60}$ ${ }_{90} \mathrm{~K}_{60}$, for maize $-\mathrm{N}_{60-90} \mathrm{P}_{60-90} \mathrm{~K}_{60}$, organic variant manure 30-40 t.ha ${ }^{-1}$ (an equivalent dose) for all crops except peas. On variants with mineral fertilizers, the content of mobile phosphorus increased to $3,0-4,0$ $\mathrm{mg} .100 \mathrm{~g}^{-1}$ soil, on the organic variant it increased to 2,78-4,28 mg.100 $\mathrm{g}^{-1}$ soil. The content of mobile phosphorus in the soil on variants without fertilizers (natural fertility of Calcareous chernozem) began to decrease and reached $0,7-0,9 \mathrm{mg} \cdot 100 \mathrm{~g}^{-1}$ of soil, or two times less than its initial content in 1953. 


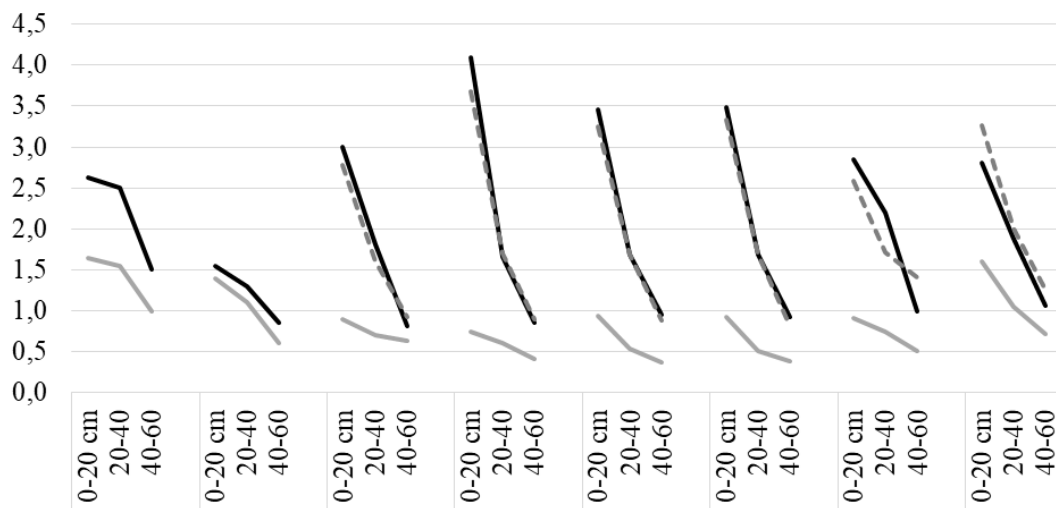

1953-1962 1963-1972 1973-1980 1981-1988 1989-1996 1997-2005 2006-2013 2014-

$\begin{array}{lll}\text { Without fertilizers } & -\mathrm{N} 120 \mathrm{P} 90 \mathrm{~K} 90 \quad \ldots-\text { Manure } 24 \mathrm{t}+\mathrm{P} 30 & 2018\end{array}$

Fig. Dynamics of available phosphor, $m g .100 \mathrm{~g}^{-1}$ soil.

In the 2009-2018 period (last 2 rotations of the eight-field crop rotation), fertilizers were used in reduced doses: during sowing 100-150 kg.ha-1 of amophos and $100-150 \mathrm{~kg} . h \mathrm{-}-1$ of ammoniac. And all plant residues, including by-products of cultivated crops, were embedded in the soil layer $0-60 \mathrm{~cm}$. The amount of plowed organic mass was on averages: on variants without fertilizers 6,42 t.ha $^{-1}$ per year, including plant residues $2,76 \mathrm{t}^{-h^{-1}}$ and by-products $3,66 \mathrm{t}^{-\mathrm{ha}^{-1}}$, on variant without fertilizers - 9,54-9,68, 3,42-3,45, 6,12-6,23 t.ha ${ }^{-1}$, respectively. The balance of phosphorus, as a result of the application of plant residues, by-products and reduced doses of mineral fertilizers, became positive $+5,7 \mathrm{~kg} \cdot \mathrm{ha}^{-1}$ at the control and $+41-43 \mathrm{~kg}^{-h^{-1}}$ at variants with fertilizers, with intensity 145,6 and $221-236 \%$. The content of available phosphorus in the soil remained at a rather high level $2,80-3,26 \mathrm{mg} .100 \mathrm{~g}^{-1}$ on fertilized variants than on the control without fertilizers $1,60-1,73 \mathrm{mg} .100 \mathrm{~g}^{-1}$.

The systematic use of $\mathrm{P}_{60-90}$ in the composition of complete mineral fertilizers increased the content of available phosphorus in the $0-20 \mathrm{~cm}$ layer from 3,0 to $4,0 \mathrm{mg} .100 \mathrm{~g}^{-1}$ soil by comparison $0,7-0,9 \mathrm{mg} .100$ $\mathrm{g}^{-1}$ soil in plots with natural fertility, in lower layers this content decreased during rotations on average from 1,8 to $0,8 \mathrm{mg} .100 \mathrm{~g}^{-1}$ soil in fertilized variants and from 0,7 to $0,4 \mathrm{mg} .100 \mathrm{~g}^{-1}$ soil in the control. The optimal content of available phosphorus in the soil for winter wheat is 3,0-4,0 mg. $100 \mathrm{~g} \mathrm{~g}^{-1}$.

Plant residues and the by-products of cultivated crops equalized the balance of available phosphorus in the soil and allowed to maintain its level at the control with natural fertility, using mineral fertilizers in small doses increased the content of mobile forms of phosphorus in the soil to $3,3 \mathrm{mg} .100 \mathrm{~g}^{-1}$. On plots with natural fertility of Calcareous chernozem (without fertilizers), the content of available phosphorus decreased in the topsoil (in the 0-20 cm layer) from 1,65 (in the $1953-1962$ period) to $0,91 \mathrm{mg} .100 \mathrm{~g}^{-1}$ soil (in the 2006-2013 period), in the $20-40 \mathrm{~cm}$ layer from 1,55 to $0,75 \mathrm{mg} .100 \mathrm{~g}^{-1}$ soil, in the $40-60 \mathrm{~cm}$ layer - from 1,0 to $0,5 \mathrm{mg} .100 \mathrm{~g}^{-1}$ soil. After introducing of crop residues and all by-products this content was $1,6,1,1$ and $0,7 \mathrm{mg} .100 \mathrm{~g}^{-1}$ soil, respectively.

Conclusions. The systematic use of fertilizers during four rotations of 8-field crop rotation (in the 1973-2005 period) increased the content of available phosphorus in Calcareous chernozem of Moldova by 2,7-2,9 times as compared with its initial content of $1,65 \mathrm{mg} .100 \mathrm{~g}^{-1}$ in 1953. The use of low doses of mineral fertilizers in the last two rotations (in the 2006-2018 period), together with plant residues and by-products, slightly reduced this content, but with time it allowed to maintain its level. On plots with natural fertility of Calcareous chernozem (without fertilizers), the content of available phosphorus decreased in the topsoil from 1.65 (in the 1953-1962 period) to $0,91 \mathrm{mg} .100 \mathrm{~g}^{-1}$ soil (in the 2006-2013 period), after introducing of crop residues and all byproducts this content was $1,6 \mathrm{mg} .100 \mathrm{~g}^{-1}$ soil.

\section{References}

1. Andries S. V. Agrochemistry of nutrients. Soil fertility and ecology: monograph / resp. edit. S. Toma. Chisinau: Pontos, 2011. 232 p.

2. Arinuchkina E. V. Soil Chemical Analysis Guide. Moscow: MGU, 1970. 485 p.

3. Indoitu D. M. Improvement of the method of preparation of the mobile phosphate extract and potassium exchangeable solution from the soil according to the Macighin method. Agricultural Science. 2016. № 1. P. 9-12.

4. Krupenikov I. A., Boinchan B. P. Chernozioms and ecological agriculture. Balti, 2004. 169 p.

5. Makarov M. I. Phosphorus of soil organic matter. Moscow: GEOS, 2009. 397 p.

6. Zagorcea C. L. Optimization of the fertilizer system in field crop rotations: monograph / resp. edit. V. G. Ungurean. Chisinau: Stiinta, 1990. 288 p.

Стаття надійшла 17.05.2019. 